\title{
A Case of Negative Pressure Treatment on Necrotizing Fasciitis
}

\author{
Sunjoo Lee, Heejin Kim and Tack-Kyun Kwon \\ Department of Otorhinolaryngology, Seoul National University College of Medicine, Seoul, Korea
}

\author{
괴사성 근막염에서 음압 상처치료 1 예 \\ 이선주 · 김희진 · 권택균 \\ 서울대학교 의과대학 이비인후과학교실
}

\author{
Received June 28, 2012 \\ Revised August 20, 2012 \\ Accepted August 23, 2012 \\ Address for correspondence \\ Tack-Kyun Kwon, MD \\ Department of Otorhinolaryngology, \\ Seoul National University \\ College of Medicine, \\ 101 Daehak-ro, Jongno-gu, \\ Seoul 110-744, Korea \\ Tel $+82-2-2072-0738$ \\ Fax $+82-2-745-2387$ \\ E-mail kwontk@snu.ac.kr
}

\begin{abstract}
Necrotizing fasciitis is an invasive soft tissue infection that progresses rapidly. It rarely occurs in the craniocervical area but when it does, it can be fatal; an early diagnosis and treatment would be thus important. Patients with necrotizing fasciitis are treated with intravenous antibiotics after wide debridement of necrotic tissues and daily dressing with antibiotic solution. Since daily dressing is thought to be a bothering procedure to both patients and medical doctors, we applied negative pressure wound therapy on the necrotizing fasciitis wound after operation. Negative pressure wound therapy has been used broadly in the departments of plastic surgery, orthopedic surgery and urology but rarely in the department of otorhinolaryngology. After applying the negative pressure wound therapy, the wound was successfully healed. We hereby introduce the benefits of negative pressure treatment on necrotizing fasciitis patients.
\end{abstract}

Korean J Otorhinolaryngol-Head Neck Surg 2012;55:791-4

Key Words Neck · Necrotizing fasciitis · Negative-pressure wound therapy.

\section{서 론}

경부 괴사성 근막염은 근막을 따라 빠르게 진행하면서, 침 범된 조직의 허혈과 괴사를 일으켜 주변 피부, 피하조직, 근육 과 주변 연부조직을 광범위하게 손상시킨다. 또한 국소적으로 호흡기 폐색, 경정맥 폐색, 폐농양, 종격동염 등의 합병증을 일 으키며, 전신적으로는 패혈증, 신부전, 쇼크 등을 일으키면서 사망할 수도 있는 치명적인 질환이다. ${ }^{1)}$ 기존의 경부 괴사성 근 막염의 치료는 광범위한 항생제 투여 및 절개 배농 후, 반복적 으로 괴사된 조직을 절제하고 항생제가 섞인 용액으로 반복적 으로 세척하는 것으로 알려져 있다. ${ }^{2}$ 하지만 반복적인 괴사조 직 절제와 항생제 용액의 세척은 환자 및 의료진에게 고통스럽 고 번거로운 치료로 인식되어 있다.

음압 상처 치료는 상처 부위에 지속적인 음압을 가하면서 괴사된 조직을 제거하여 세포 재생을 돕는 치료 방법으로 정
형외과, 성형외과, 비뇨기과 등에서 관절부위 상처, 욕창 등의 상처에 광범위하게 사용되어 왔다. ${ }^{3)}$ 본 교실에서는 음압 상처 치료를 고전적인 치료로 호전되지 않는 경부 괴사성 근막염의 치료에 적용하여 성공적으로 상처를 치료하였다. 이 사례를 소 개함으로써 음압 상처 치료가 이비인후과 영역에서도 유용하 게 적용할 수 있음을 문헌 고찰과 함께 보고하고자 한다.

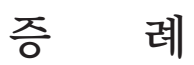

46세 남자 환자가 내원 3일 전부터 시작된 우측 협부 통증 및 부종으로 응급실을 통해 내원하였다. 내원 당시 경부까지 진행된 염증 소견을 보여 경부 컴퓨터단층촬영 $(\mathrm{CT})$ 을 통한 상 처 평가를 권유하였으나 환자가 거부하고 자의로 귀가한 후 추 적 관찰이 중단되었다. 그로부터 3주 뒤 환자는 협부, 경부와 좌측 상박의 부종 및 통증으로 다시 응급실로 내원하였다. 환 
자는 만성 알코올 중독자로 하루 소주 2 3병의 음주력을 가지 고 있었으나 그 외 당뇨, 고혈압 등의 과거력은 없었으며 고시 원에서 혼자 거주하고 있었다. 내원 당시 체온은 $36.7^{\circ} \mathrm{C}$, 호흡 수는 20회로 호흡곤란을 호소하지는 않았으며, 혈압은 130/ $59 \mathrm{mmH}_{2} \mathrm{O}$, 심박동수는 92회/분으로 신체 활력 징후의 이상 을 보이지 않았다. 이학적 검진상 상기도의 부종은 없었으며 경부, 흥부, 좌측 상박에 부종 및 피부의 홍반이 관찰되었고, 부종이 관찰되는 곳에서 피부를 누를 때 염발음이 있었다(Fig. 1). 혈액 검사에서 $\mathrm{WBC} 17.10 \times 10^{3} / \mu \mathrm{L}, \mathrm{Hb} 11.8 \mathrm{~g} / \mathrm{dL}$, platelet $167 \times 10^{3} / \mu \mathrm{L}, \mathrm{ESR} 28 \mathrm{~mm} / \mathrm{hr}$ 으로 염증수치가 증가한 양 상을 보였다.

응급실에서 촬영한 CT 소견상(Fig. 2) 우측 저작근 공간에 서 인두 주변 공간, 종격동을 걸쳐 좌측 상박에 이르기까지 근막층을 따라 광범위한 공기음영 및 농양이 관찰되었다. 이 에 이학적 소견과 CT 소견을 바탕으로 괴사성 근막염 및 심
부 경부 감염으로 진단하여, 응급 광범위 괴사조직 절제 수술 을 시행하였다. 수술은 상박과 종격동염으로 인하여 정형외 과, 흥부외과와 협진으로 시행하였다. 수술시에 악취를 동반 한 조직액 및 농양과 광범위하게 괴사된 근막이 발견되어 배 액을 시행하고 괴사된 조직을 절제하였으며, 베타딘액으로 세 척 후 총 13 개의 배액관을 흉부와 경부에 삽입하였다. 술 중 시행한 괴사된 세포 조직액의 세균 배양 검사 결과 methicillin-resistant Staphylococcus aureus(MRSA)가 동정되어 ceftriaxone, clindamycin, 그리고 vancomycin을 이용한 정 맥 항생제 치료를 시작하였다. 또한 하루에 2회씩 베타딘 용액 을 이용한 세척 치료를 삽입한 배액관을 통하여 시행하였다. 수술 후 3일째 피부 괴사 범위가 진행되어 베타딘 용액 세척 치 료가 충분하지 않다고 판단되어 수술 당시 봉합하였던 절개부 위를 개방하였고, 근막층에 남아있는 농양을 확인하였다(Fig. 3A). 이에 잔여 농양 및 심하게 괴사된 피부와 피하조직(Fig.
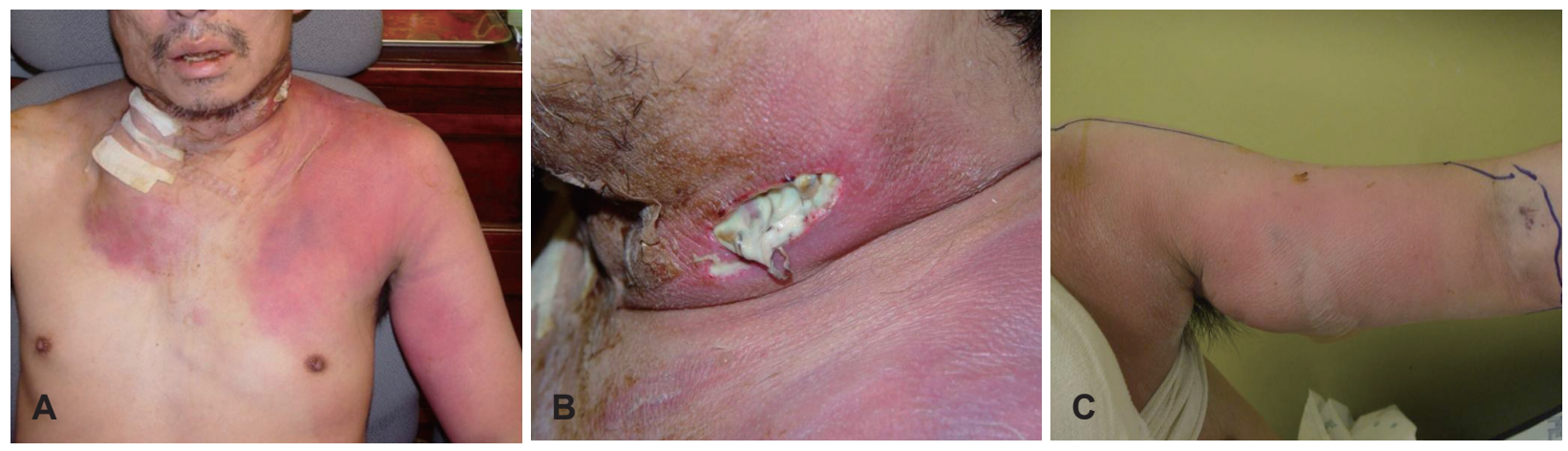

Fig. 1. External photo shows the reddish color change of skin on the neck extends to left anterior chest and left upper arm (A). Necrotic soft tissue and pus discharge (B) was seen on the left neck, and bulla formation (C) was also presented in the left upper arm.
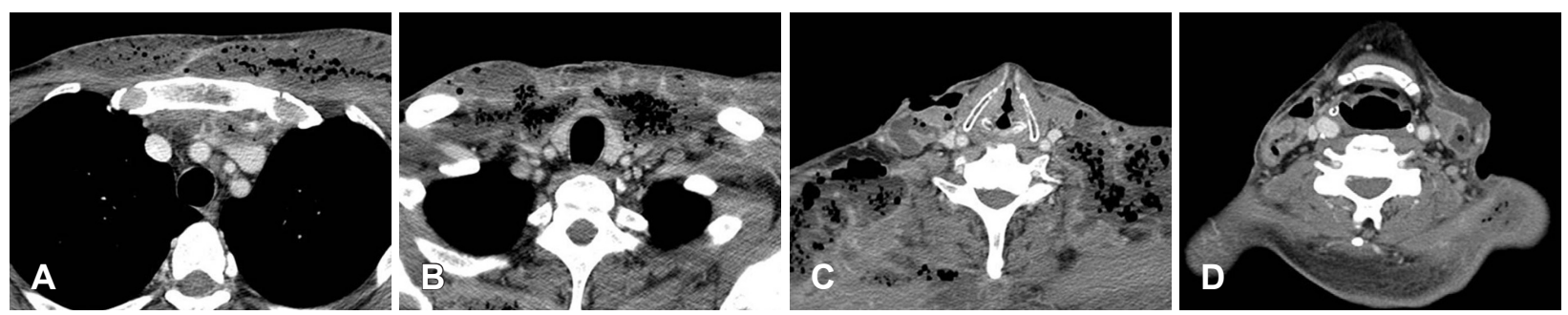

Fig. 2. There was diffuse air bubble shadow with abscess formation along the fascia layer at the anterior chest (A), around the thyroid (B) and thyroid cartilage (C). Despite of abscess and gas formation, airway seemed to be intact (D).

Fig. 3. Remaining profuse pus discharge on wound (A). Necrosis of skin flap (B).
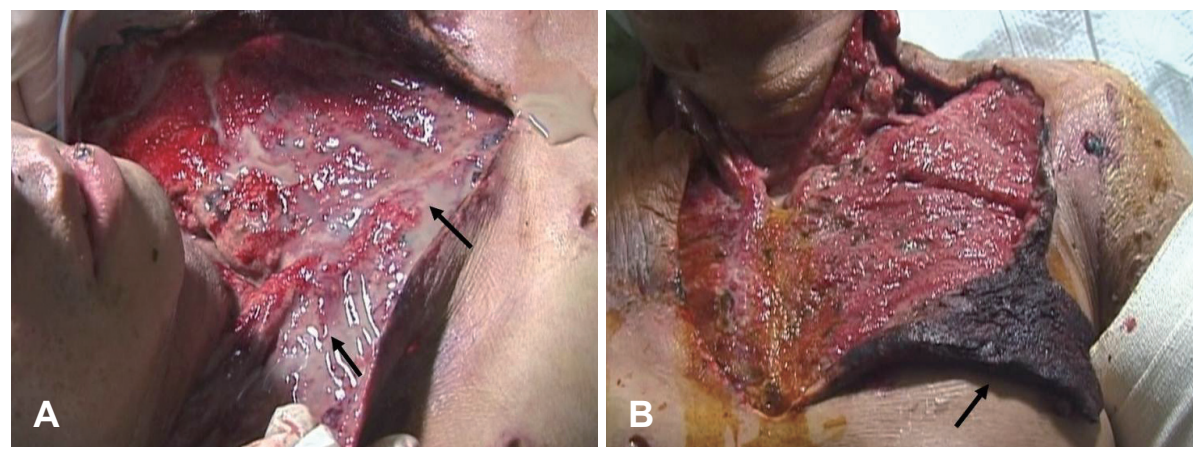
Fig. 4. Negative pressure wound therapy applied wound (A). After removal of dressing $(B)$.
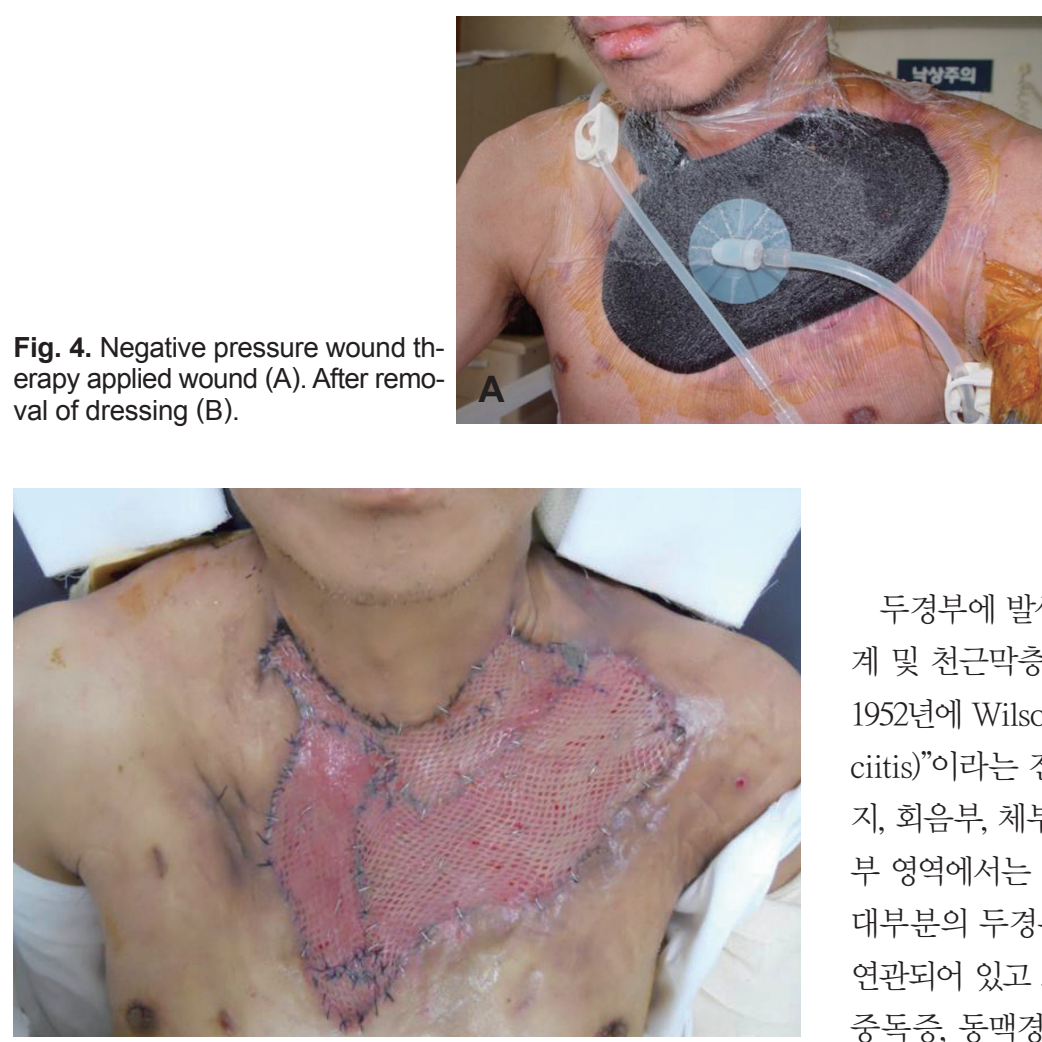

Fig. 5. Split thickness skin graft state.

$3 \mathrm{~B})$ 을 추가적으로 광범위하게 제거하였다. 또한 환자의 환부 가 광범위한 피부 결손을 포함하고 있으며 일반적인 소독 치 료로 효과적인 배액이 되지 않을 것으로 판단하여, 음압 상처 치료를 경부 및 전흥부에 적용하였다.

음압 상처 치료의 시행 방법은 먼저 환부의 크기에 맞추어 스 펀지를 잘라 상처부위를 덮고, 접착 필름을 스펀지를 덮을 만 큼 충분한 크기로 자른 후, 그 위에 연결관을 붙이는 것으로 상 처에 공기가 들어가지 않도록 밀폐하여 상처부위에 붙이도록 한다. 이 때 환부 주변의 피부는 밀폐를 위해 건조한 상태로 유 지해야 한다. 완전히 밀폐된 것을 확인 후 연결관을 음압 생성 장치에 연결하며, 음압은 $100 \mathrm{~mm} \mathrm{Hg}$ 로 유지하였고 음압 치 료 장치는 3 일마다 교체하였다. 경부의 음압 상처 치료를 시작 하고 10 일 후 경과 관찰을 위해 시행한 경부 CT에서 경부는 호전 양상을 보였으나 우측 상배부의 잔여 농양이 발견되어, 추가적인 절개 배농술 시행 후 상배부 역시 음압 상처 치료를 적용하였다. 음압 상처 치료 시작 25 일 후 경부 및 상배부 환 부의 농양은 모두 호전되었으며(Fig. 4), 연부 조직 상태 또한 회복되어 부분층 피부이식을 시행하였고, 이식된 조직은 성공 적으로 생착하였다(Fig. 5). 환자는 특별한 합병증 없이 퇴원 하였고 외래 경과 관찰시에도 경미한 피부 수축 이외에 특이 소견 없이 완치되었다.

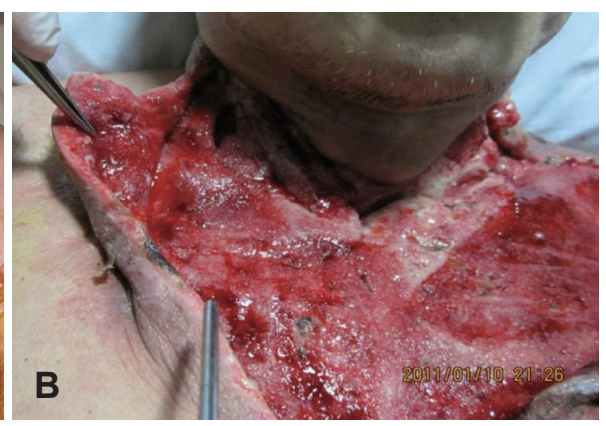

\section{고 찰}

두경부에 발생하는 괴사성 근막염은 경부의 표재성 근건막 계 및 천근막층을 침범하는 진행성의 중증 세균성 감염으로, 1952년에 Wilson"이 처음으로 "괴사성 근막염(necrotizing fasciitis)"이라는 진단명을 사용하였다. 괴사성 근막염은 주로 사 지, 회음부, 체부에 많이 발생하는 것으로 알려져 있으며, 두경 부 영역에서는 전체의 약 $10 \%$ 정도로 드물게 보고되고 있다. ${ }^{5)}$ 대부분의 두경부 영역의 괴사성 근막염은 치주염이나 외상과 연관되어 있고 호발하는 연령이나 성은 없으며 당뇨병, 알코올 중독증, 동맥경화증, 점액부종, 에이즈 감염, 고령, 만성 신부 전증, 영양실조증 및 전이성암 등과 같은 전신 상태와도 연관 이 있다고 보고되고 있다.6) 또한 건강한 사람에서도 감염성 질 환, 외상이나 수술력 없이 발생되는 경우도 보고된 바 있다.) 본 사례는 특이 병력 없는 젊은 남자 환자이지만, 만성 알코올 중독증과 사회적 고립으로 인한 장기간의 영양 결핍 등을 위 험 인자로 고려할 수 있다.

괴사성 근막염은 수술시 근육층과 피하지방층 사이가 쉽 게 박리되며 근육층은 보존되어 있는 반면 근막의 괴사가 뚜 렷하고, 피하지방층이 액화성 괴사되어 나오는 악취가 심한 회 갈색의 구정물 같은 농이 관찰된다. 수술 전 임상적 진단을 위 해 방사선학적 소견이 도움이 될 수 있는데, 단순 X-선 검사에 서 연부조직의 공기 음영이 발견되거나, CT에서 근막층의 공 기음영이 발견되는 경우가 많다. 또한 $\mathrm{CT}$ 를 통해 병의 진행 정 도와 기포의 형성, 초기 감염 부위 및 합병증의 유무를 판단 할 수 있다.

괴사성 근막염의 기본적인 치료 방침은 강력한 항생제 치 료와 함께 광범위한 수술적 치료를 시행하는 것이다. 괴사성 근막염을 일으키는 원인균은 호기성-혐기성균의 혼합감염에 의한 경우, A-군 연쇄구균 감염, 그리고 clostridium perfringens 감염의 세 군으로 나뉜다. ${ }^{8)}$ 따라서 항생제는 3 세대 cephalosporin, aminoglycoside 그리고 clindamycin(혹은 metronidazole) 정주 치료를 한다. 하지만 본 사례의 경우는 MRSA가 동정되어 vancomycin을 추가하여 치료하였다. 한 
편 수술적 치료 방법으로 광범위한 괴사 조직의 제거와 근막 절개 및 배농 등이 포함되어야 한다. ${ }^{9}$ 이는 병변 부위의 허혈 과 괴사 작용이 항생제의 침투를 어렵게 하여 항생제의 효과 를 감소시키는 역할을 하기 때문이다. ${ }^{10)}$ 따라서 광범위한 절개 배농과 괴사조직을 제거한 후 추가적으로 베타딘 용액으로 상 처부위를 세척하는 치료가 필요하다. ${ }^{2}$ 본 사례는 광범위한 괴 사성 근막염으로 기존의 베타딘을 이용한 세척 치료 방법으 로 효과적인 치료가 되지 않아, 음압 상처 치료를 적용하여 효 과적으로 치유가 되었다.

음압 상처 치료는 1990년대 초 Wake Forest University (Winston-Salem, NC, USA)에 의해 개발되었고 ${ }^{11)}$ 현재 미국 Food and Drug Administration에서는 만성 또는 급성 외상 성 상처, 벌어진 상처, 부분층 화상, 당뇨 혹은 욕창에 의한 궤 양성 상처, 이식조직 상처 등을 음압 상처 치료의 적응증으로 제안하고 있다. ${ }^{12)}$ 음압 상처 치료는 밀폐된 공간에 연결된 튜 브 끝에 진공펌프를 연결하여 $50 \sim 125 \mathrm{~mm} \mathrm{Hg}$ 정도의 음압 을 유지하여 환부에서 발생하는 괴사 조직 및 삼출액을 제거 하는 치료이다. ${ }^{13)}$ 음압 상처 치료의 상처 회복 기전은 명확하게 증명된 바 없으나, 2009년 Orgill 등ㄴ)은 음압 상처 치료가 상 처의 부종을 줄여 조직압을 낮추어 혈류량을 증가시키고, 혈 류량 증가로 조직으로의 산소 및 영양 공급이 늘어난다고 하 였다. 또한 상처의 염증성 조직 분해효소와 싸이토카인을 제 거하며 지속적인 물리적 자극으로 세포 재생을 촉진한다고 보 고하였다. 아직까지 음압 상처 치료에 대한 대규모 연구가 이 루어진 바가 없어 고전적인 상처 치료보다 우월함을 입증할 수 없으나, 음압 상처 치료가 치료 과정 중 환자의 통증이 덜하여 더 적은 양의 진정제 및 진통제가 필요하다는 장점이 있다. ${ }^{15)}$ 또한 베타딘 용액으로 하루에 여러 번 세척 치료를 시행하는 것에 비해, 음압 상처 치료는 적용 후 3일에 한번 교체함으로 써 환자의 입장에서 번거로움을 줄여 주고 의료진의 입장에서 도 수고를 덜 수 있으며, 환부가 밀폐되고 항상 음압이 걸려 있 어 조직액 및 괴사액을 효과적으로 제거하여 이차적인 감염 을 막을 수 있다. 하지만 상처 음압 장치를 교체할 때를 제외 하고는 병변 부위를 관찰할 수 없는 단점이 있다.

음압 상처 치료를 위한 장비는 경제적으로도 부담스럽지 않 은 정도의 가격으로 상품화되어 있으며 상처의 크기에 따라 종류도 다양하여 선택의 폭이 넓고, 비용대 효과 면에서 우수 하다.

괴사성 근막염은 27 40\%의 사망률을 보이는 치명적인 질
환으로, 예후가 치료의 시작 시점과 밀접하게 연관되어 있으 므로 빠르고 적절한 치료가 중요하다. ${ }^{16)}$ 고전적인 치료만으로 호전되지 않는 두경부의 괴사성 근막염에 음압 상처치료를 도 입하여 효과적으로 치유된 사례를 소개함으로써 이비인후과 영역, 특히 두경부 영역에서 추후 음압 상처 치료가 효과적으 로 적용될 수 있기를 희망한다.

\section{REFERENCES}

1) Sonne JE, Kim SB, Frank DK. Cervical necrotizing fasciitis as a complication of tonsillectomy. Otolaryngol Head Neck Surg 2001; 125(6):670-2.

2) Mihos P, Potaris K, Gakidis I, Papadakis D, Rallis G. Management of descending necrotizing mediastinitis. J Oral Maxillofac Surg 2004;62(8):966-72.

3) Chio EG, Agrawal A. A randomized, prospective, controlled study of forearm donor site healing when using a vacuum dressing. Otolaryngol Head Neck Surg 2010;142(2):174-8.

4) Wilson B. Necrotizing fasciitis. Am Surg 1952;18(4):416-31.

5) Chan $\mathrm{CH}$, McGurk M. Cervical necrotising fasciitis--a rare complication of periodontal disease. Br Dent J 1997;183(8):293-6.

6) Whitesides L, Cotto-Cumba C, Myers RA. Cervical necrotizing fasciitis of odontogenic origin: a case report and review of 12 cases. J Oral Maxillofac Surg 2000;58(2):144-51; discussion 152.

7) Rouse TM, Malangoni MA, Schulte WJ. Necrotizing fasciitis: a preventable disaster. Surgery 1982;92(4):765-70.

8) Braunwald E, Fauci AS, Kasper DL, Hauser SL, Longo DL, Jameson JL. Streptococcal and enterococcal infections. In: Braunwald E, editor. Harrison's principles of internal medicine. 15th ed. USA: McGraw-Hill; 2001. p.901-9.

9) Banerjee AR, Murty GE, Moir AA. Cervical necrotizing fasciitis: a distinct clinicopathological entity? J Laryngol Otol 1996;110(1):81-6.

10) Corsten MJ, Shamji FM, Odell PF, Frederico JA, Laframboise GG, Reid KR, et al. Optimal treatment of descending necrotising mediastinitis. Thorax 1997;52(8):702-8.

11) Argenta LC, Morykwas MJ. Vacuum-assisted closure: a new method for wound control and treatment: clinical experience. Ann Plast Surg 1997;38(6):563-76; discussion 577.

12) US Department of Health \& Human Services. Agency for Healthcare Research and Quality. Technology assessment: negative pressure wound therapy devices. Available from: URL: http://www.fda.gov/ forconsumers/consumerupdates/ucm193277.htm.

13) Ubbink DT, Westerbos SJ, Nelson EA, Vermeulen H. A systematic review of topical negative pressure therapy for acute and chronic wounds. Br J Surg 2008;95(6):685-92.

14) Orgill DP, Manders EK, Sumpio BE, Lee RC, Attinger CE, Gurtner $\mathrm{GC}$, et al. The mechanisms of action of vacuum assisted closure: more to learn. Surgery 2009;146(1):40-51.

15) Stansby G, Wealleans V, Wilson L, Morrow D, Gooday C, Dhatariya K. Clinical experience of a new NPWT system in diabetic foot ulcers and post-amputation wounds. J Wound Care 2010;19(11):496, 498502 .

16) Roberson JB, Harper JL, Jauch EC. Mortality associated with cervicofacial necrotizing fasciitis. Oral Surg Oral Med Oral Pathol Oral Radiol Endod 1996;82(3):264-7. 